\title{
The Joint FASB/IASB Lease Project: Discussion And Industry Implications
}

John Kostolansky, Loyola University Chicago, USA Brian Stanko, Loyola University Chicago, USA

\begin{abstract}
Over several decades, the Financial Accounting Standards Board and International Accounting Standards Board have enacted numerous changes to the controversial lease accounting rules. As currently prescribed, operating leases are treated as rental arrangements whereby the lessee does not record a liability - a situation generally referred to as off-balance sheet financing. In an attempt to increase transparency and comparability, the FASB and IASB will soon require all leases to be capitalized. This paper quantifies the impact of the new leasing standard on the financial statements and ratios of the firms and industries represented in the $S \& P 100$ under a variety of discount rates.
\end{abstract}

Keywords: Operating Leases; Capital/Financing Leases; Off-Balance Sheet Financing; FASB; IASB; Topic 840

\section{INTRODUCTION}

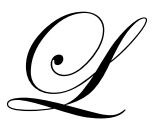

ease accounting is controversial because significant amounts of future lease payments go unreported as liabilities on the balance sheet. As currently prescribed, operating leases are treated as rental arrangements whereby the lessee does not record a liability - a situation generally referred to as offbalance sheet financing. In August 2010, the Financial Accounting Standards Board (FASB) and the International Accounting Standards Board (IASB) jointly issued exposure drafts for a proposed new lease accounting standard. Under the proposed standard, operating leases will not only be recognized in the balance sheet, but the resulting assets and liabilities will be measured under "the longest possible lease term that is more likely than not to occur" (FASB Proposed Accounting Standards Update, Leases, p. 2).

At the date of initial application, which has yet to be determined, measurement of the resulting assets and liabilities will be based upon the remaining lease payments (FASB Exposure Draft, Leases, p. 123). The purpose of this study is to quantify the impact of the new leasing standard on the financial statements and their related ratios across the variety of firms and industries represented in the S\&P 100. To provide a range of magnitude, this study measures the impact of applying the new standard using multiple discount rates of 3\%, 6\%, and $9 \%$.

\section{RESEARCH METHOD}

For this study, we analyzed the leasing arrangements of the Standard and Poor's 100 (S\&P 100) companies by extracting Form 10-K information from the Management Discussion and Analysis note, the financial statements, and the leasing footnotes. Previous studies of operating leases focused on small, paired samples of companies with and without operating leases (Imhoff, Lipe, and Wright 1991) or on firms in particular industries such as airlines and grocery (Imhoff, Lipe, and Wright 1993) and retail (Mulford 2007). These studies found significant results from capitalizing the leases of U.S. companies. Similar conclusions of significant change were also found outside the U.S. in the Beattie et al. (1998) study of U.K. firms, the Bennet and Bradbury (2003) study of New Zealand firms, and in the Fülbier et al. (2008) study of German firms.

This study differs from those previously cited in that we provide measures of impact using multiple discount rates, $3 \%, 6 \%$, and $9 \%$, rather than a single rate. This obviously allows the reader to see the financial impact given a particular discount rate. Further, varying rates provide information about the magnitude of lease 
liabilities during a period of time when interest rates have significantly declined. In addition, our analysis provides industry specific insights across the S\&P 100 firms, rather than preselecting a particular industry. Given the findings in the previously cited studies, we expect to find a significant change in the assets, liabilities and related financial ratios of firms that presently utilize operating leases.

To approximate the effect of capitalizing operating leases, we adapt the approach originally developed by Imhoff, Lipe, and Wright, utilizing the required $10-\mathrm{K}$ disclosures of the minimum payments due for operating leases in each of the next five years individually and the aggregate balance of the operating lease payments beyond five years. To illustrate our methodology, consider the operating lease disclosure of the first company in the S\&P 100 list, ALCOA.

In its 2008 Annual Report 10-K, ALCOA's leasing footnote disclosed the following information (shown in Illustration A).

Illustration A: Minimum Lease Payments Reported In ALCOA's 2008 Annual Report And Assumed Schedule Of Payments Used To Calculate The Present Value

\begin{tabular}{|cccc|}
\hline Year & $\begin{array}{c}\text { Minimum } \\
\text { Lease payments }\end{array}$ & $\begin{array}{c}\text { Assumed } \\
\text { Schedule of payments }\end{array}$ & $\begin{array}{c}\text { Payment } \\
\text { assumed at end of year }\end{array}$ \\
\hline 2009 & $\$ 398$ & $\$ 398$ & 2009 \\
2010 & 320 & 320 & 2010 \\
2011 & 215 & 215 & 2011 \\
2012 & 113 & 113 & 2012 \\
2013 & 139 & 139 & 2013 \\
Thereafter & $\underline{321}$ & 139 & 2014 \\
Total & $\underline{\underline{11,506}}$ & 139 & 2015 \\
& & $\underline{\underline{43}}$ & 2016 \\
& & & \\
\hline
\end{tabular}

As noted above, ALCOA reports operating lease payments individually for the years 2009 through 2013. To calculate the present value of all the lease payments, the pattern of payments after 2013 ( $\$ 321$ in total) must be specified. We employ a simple assumption that lease payments after 2013 will continue at the same amount as the fifth payment (i.e., \$139) until payments accumulating to $\$ 321$ have been made.

As the two right columns in Illustration A show, operating lease payments of $\$ 139$ are assumed for 2014 and 2015 (the same as 2013, the fifth year), with the remainder of $\$ 43$ assumed for 2016. For the other S\&P 100 firms, we use the same assumption to spread the aggregate payment beyond the fifth year into however many additional years are required. The present value of the assumed payments is the estimated liability and asset resulting from capitalizing the operating leases.

To calculate the present value of the payments, a firm's incremental borrowing rate should be used (FASB Exposure Draft, Leases, p. 58, BC194). Despite this requirement, most leasing studies have used a fixed discount rate for the entire sample (reported in Fülbier et al. 2008, p. 127, to often be 10\%). The Fülbier study employed company-specific discount rates for most companies in their sample, but resorted to using a median rate for 23 firms whose rate could not be found. The estimate of the liability in studies of international firms is hampered due to the less-detailed lease disclosures provided outside the U.S. before IFRS and/or the use of an assumption that the lease payments will continue for a fixed period time (e.g., 10 years). Recognizing the difficulty of identifying a firm's incremental borrowing rate, we chose to estimate the lease liability under several interest rate assumptions which provides the reader an approximation of the upper, middle, and lower limits of the impact of the new standard.

The present study customizes the payment period based on each firm's leasing payment disclosure (as explained in Illustration A). Since current interest rates are far lower than the $10 \%$ used in many previous studies and it is difficult to predict future borrowing rates, we chose to measure the lease liability using multiple rates of $3 \%, 6 \%$, and $9 \%$. Thus, our approach will offer a range of impact of capitalizing the operating leases of the S\&P 100 firms. We estimate the lease-related asset and liability to be the present value of the remaining lease payments which is consistent with exposure draft requirements noted previously. 


\section{RESULTS}

Tables 1 through 3 provide the results of our analysis. As previously noted, we first estimated the impact of capitalization on total assets and total liabilities. We then recalculated two important ratios: total debt to total assets and return on total assets. All calculations were made using three discount rates: 3\%, 6\%, and 9\%. Obviously, discounting the payments at $3 \%$ will yield the highest present value measure of the operating lease payments and $9 \%$, the lowest. We present the majority of our analysis using the $6 \%$ discount rate to provide the middle ground of results. We also identify how specific industries will be affected.

\section{Impact on Total Debt}

In order to establish the effect of operating lease capitalization on the total debt to total assets (TD/TA) ratio, we first calculated the change in total debt resulting from lease capitalization. These aggregated results are shown in Table 1.

Table 1: Changes to Selected Financial Measures of the S\&P 100 Companies When Operating Lease Are Capitalized Using Selected Discount Rates

\begin{tabular}{|c|c|c|c|}
\hline & \multicolumn{3}{|c|}{ Discount Rate } \\
\hline & $3 \%$ & $6 \%$ & $9 \%$ \\
\hline \multicolumn{4}{|l|}{ Increase in Total Liabilities } \\
\hline Average increase & $12.10 \%$ & $10.39 \%$ & $9.45 \%$ \\
\hline Largest increase & $281.29 \%$ & $231.58 \%$ & $204.85 \%$ \\
\hline Median increase & $4.14 \%$ & $3.90 \%$ & $3.64 \%$ \\
\hline \multicolumn{4}{|l|}{ Increase in Total Assets } \\
\hline Average increase & $5.93 \%$ & $5.10 \%$ & $4.44 \%$ \\
\hline Largest increase & $119.76 \%$ & $98.59 \%$ & $82.19 \%$ \\
\hline Median increase & $2.59 \%$ & $2.305 \%$ & $2.03 \%$ \\
\hline Average Total Debt/Total Assets Ratio & $66.52 \%$ & $66.29 \%$ & $66.10 \%$ \\
\hline \multicolumn{4}{|l|}{ (Excluding operating leases: $64.48 \%$ ) } \\
\hline \multicolumn{4}{|l|}{ Change in Total Debt/Total Assets Ratio } \\
\hline Average increase & $4.64 \%$ & $4.12 \%$ & $3.68 \%$ \\
\hline Largest increase & $73.50 \%$ & $66.96 \%$ & $60.85 \%$ \\
\hline Median increase & $1.26 \%$ & $1.12 \%$ & $1.04 \%$ \\
\hline Average Return on Assets Ratio & $6.81 \%$ & $6.85 \%$ & $6.88 \%$ \\
\hline \multicolumn{4}{|l|}{ (Excluding operating leases: $7.12 \%$ ) } \\
\hline \multicolumn{4}{|l|}{ Change in Return on Assets Ratio } \\
\hline Average decrease & $-4.66 \%$ & $-4.14 \%$ & $-3.71 \%$ \\
\hline Largest decrease & $-54.50 \%$ & $-49.65 \%$ & $-45.11 \%$ \\
\hline Median decrease & $-2.53 \%$ & $-2.24 \%$ & $-1.99 \%$ \\
\hline
\end{tabular}

Note that the average increase in total liabilities for all companies ranges from $9.45 \%$ (using a $9 \%$ discount rate) to $12.10 \%$ (using a 3\% discount rate). The median increase for the S\&P 100 is over 3.64\%. The largest increase in liabilities for a single firm is over $200 \%$ under any of our discount rates (See Table 3, Walgreen's). Obviously, the choice of discount rate has a significant impact on the outcome. 


\section{Impact on Total Debt to Total Assets}

Given that assets generally exceed liabilities, the impact of operating lease capitalization on total assets is not as significant as the increase in total liabilities. However, the impact on TD/TA is still noteworthy. Table 1 reveals that the average TD/TA ratio of the S\&P 100 firms increases from $64.48 \%$ excluding operating leases to $66.29 \%$ if operating leases are discounted at $6 \%$. Again referring to Table 1, it can be seen that the total debt to total asset ratio will increase significantly under all interest rate assumptions with a median increase over $1 \%$. Walgreen's again experienced the largest increase in TD/TA of over $60 \%$ (see Table 3 ).

\section{Impact on Return on Assets}

As noted above, changes in total assets affect the TD/TA ratio. Likewise, changes in total assets affect a company's return on assets (ROA) ratio, as do changes to net income. We calculate ROA as 2008 net income divided by the restated value for total assets, which will be the initial impact at adoption of the new standard.

Subsequent to capitalization, depreciation expense on the leased asset and interest expense on the lease liability will replace rent expense in computing net income. As was demonstrated by Ingberman et al. 1974, "total lease expense under capitalization will initially exceed expense under an operating lease (p. 28)." This is due to greater effective interest on a higher lease liability during the early years of the leased asset's life. Thus, the numerator of the ROA ratio, net income, will initially be lower under capitalization while the denominator, total assets, will be higher. Over time, the capitalized lease asset will, of course, depreciate in value. The present study, however, focuses on the immediate impact of implementing the new standard; thus, we do not adjust net income to compute the initial ROA ratio estimate.

Capitalizing the operating leases will significantly decrease the ROA measure. Table 1 reveals that average ROA for the S\&P 100 would fall from $7.12 \%$, excluding operating leases, to $6.85 \%$ using the $6 \%$ discount rate. Referring again to Table 1, the median firm will experience a decline of over $2 \%$. Walgreen's again experienced the largest decrease, between $45.11 \%$ and $54.50 \%$ under our assumptions (Table 3 ).

\section{Impact on Selected Measures by Industry}

The above discussion provides evidence that the impact of lease capitalization on both TD/TA and ROA varies greatly across the S\&P 100 corporations. To see the impact of the new standard on specific industries, we partitioned the firms by 2-digit industry codes resulting in six identifiable industries. Table 2 identifies the number of firms in each industry group and the change in our study's various metrics by industry. "Retail Trade" is the most heavily impacted industry with an average increase in total liabilities of $43.16 \%$.

Table 2: Average Change in Total Liabilities, Total Assets, Total Debt to Total Assets Ratio, and Return on Assets S\&P 100 Companies by 2-Digit SIC Industry Code Using a 6\% Rate to Discount the Lease Payments

\begin{tabular}{|l|c|c|c|c|c|}
\hline \multicolumn{1}{|c|}{$\begin{array}{c}\text { 2-digit SIC } \\
\text { Industry Group }\end{array}$} & $\begin{array}{c}\text { Number of } \\
\text { Firms in } \\
\text { Industry }\end{array}$ & $\begin{array}{c}\text { Average Increase } \\
\text { in Total } \\
\text { Liabilities }\end{array}$ & $\begin{array}{c}\text { Average Increase } \\
\text { Average Increase } \\
\text { in Total Assets } \\
\text { in Total } \\
\text { Debt/Total } \\
\text { Assets }\end{array}$ & $\begin{array}{c}\text { Average } \\
\text { Decrease in } \\
\text { Return on Assets }\end{array}$ \\
\hline $\begin{array}{l}\text { Finance, Insurance } \\
\text { and Real Estate }\end{array}$ & 15 & $1.80 \%$ & $1.18 \%$ & $0.58 \%$ & $-1.14 \%$ \\
\hline Manufacturing & 52 & $5.00 \%$ & $2.79 \%$ & $2.03 \%$ & $-2.62 \%$ \\
\hline Mineral Industries & 4 & $14.51 \%$ & $6.58 \%$ & $7.11 \%$ & $-5.87 \%$ \\
\hline Retail Trade & 10 & $43.16 \%$ & $20.30 \%$ & $14.77 \%$ & $-13.94 \%$ \\
\hline Service Industries & 6 & $13.64 \%$ & $3.07 \%$ & $9.98 \%$ & $-2.96 \%$ \\
\hline $\begin{array}{l}\text { Transportation, } \\
\text { Communication and } \\
\text { Utilities }\end{array}$ & 13 & & & & \\
\hline S\&P average & & $13.91 \%$ & $7.65 \%$ & & $-6.14 \%$ \\
\hline
\end{tabular}


Consistent with the large impact on the liabilities of the "Retail Trade" industry group, assets of the group increased by $20.3 \%$ when operating leases are capitalized. Changes to the industry averages for TD/TA and ROA were in proportion to changes in liabilities. Retailers suffered an increase in total debt to total assets of $14.77 \%$ and a decrease in return on assets of $-13.94 \%$. The "Transportation, Communication and Utilities" group experienced the second largest impacts.

\section{Use of Operating Leases and Capital Leases by Industry}

Table 2 makes clear that some industries are less affected by lease capitalization than others, which raises the question "why?" Do firms in these industries simply have fewer leases? Do firms in these industries already capitalize their leases? Or are there other reasons for this result?

In addition to the operating lease information referenced above, our study also captured the capitalized lease disclosure in the $10-\mathrm{K}$, namely the present value of capitalized lease obligations. In answer to the above questions, we note that over half of the S\&P 100 firms have no capitalized lease liabilities whatsoever. Only ten of the 100 firms have capitalized lease obligations that exceed $1 \%$ of total assets or $1 \%$ of total liabilities. The average amount of capital lease liability for all firms was $\$ 123$ million, whereas the average amount operating lease liability at $6 \%$ was $\$ 2,821$ million. Thus, we conclude that capital leases are relatively insignificant for the companies in our study and operating leases were prevalent. We also conclude that, in industries where operating leases are little used, this situation is not caused because leases have been capitalized.

Table 2 provides contradictory information about whether capital-intensive industries are more likely to employ leases. In the Retail Trade industry group, which is comprised of so-called "big box" merchandisers like Wal-Mart and Home Depot, recognizing operating leases in the balance sheet would cause assets to increase by $20 \%$. These merchandisers require large investments in real assets. On the other hand, the Manufacturing industry group, which we also presumed to be asset-intensive, would only experience a small increase in assets (2.79\%) when their operating leases are capitalized. Thus, future research will have to determine why some industries are more likely than others to employ leases as a financing vehicle.

\section{S\&P 100 Firm Specifics}

Table 3 shows the ten S\&P 100 companies that were most affected by lease capitalization. These companies will see an extraordinary change in their reported assets, liabilities and related ratios.

Table 3: The Ten S\&P 100 Firms Most Affected By Capitalizing Operating Lease Payments (Using a 6\% Rate to Discount the Lease Payments)

\begin{tabular}{|l|c|c|c|c|}
\hline \multicolumn{1}{|c|}{ Company } & $\begin{array}{c}\text { Percentage Increase } \\
\text { in Total Liabilities }\end{array}$ & $\begin{array}{c}\text { Percentage Increase } \\
\text { in Total Assets }\end{array}$ & $\begin{array}{c}\text { Percentage Increase } \\
\text { in TD/TA }\end{array}$ & $\begin{array}{c}\text { Percentage Decrease } \\
\text { in ROA }\end{array}$ \\
\hline Walgreens & $231.58 \%$ & $98.59 \%$ & $66.96 \%$ & $-49.65 \%$ \\
\hline FedEx & $100.65 \%$ & $44.08 \%$ & $39.26 \%$ & $-30.60 \%$ \\
\hline CVS Pharmacy & $58.55 \%$ & $25.34 \%$ & $26.49 \%$ & $-20.22 \%$ \\
\hline McDonalds & $47.05 \%$ & $24.93 \%$ & $17.71 \%$ & $-19.95 \%$ \\
\hline Devon Energy & $36.94 \%$ & $17.19 \%$ & $16.85 \%$ & $-14.67 \%$ \\
\hline Dow Chemical & $32.80 \%$ & $22.64 \%$ & $8.28 \%$ & $-18.46 \%$ \\
\hline Sprint & $32.52 \%$ & $21.57 \%$ & $9.00 \%$ & $-17.74 \%$ \\
\hline Nike & $31.27 \%$ & $10.75 \%$ & $18.53 \%$ & $-9.71 \%$ \\
\hline Lowe's & $26.60 \%$ & $11.91 \%$ & $13.13 \%$ & $-10.64 \%$ \\
\hline Home Depot & $24.61 \%$ & $13.98 \%$ & $9.32 \%$ & $-12.27 \%$ \\
\hline
\end{tabular}

Walgreens, which is widely known to employ leasing to finance its new stores, leads the group with $67 \%$ increase in TD/TA and 49\% decrease in ROA. FedEx, CVS Pharmacy, and McDonalds will also be greatly affected. Sprint Nextel will see a 9\% increase in TD/TA, but its ROA will fall almost 18\%. NIKE's TD/TA will increase 18.5\%, while its ROA will decline $9.7 \%$. 


\section{CONCLUSION}

This study analyzed the leasing arrangements of the Standard and Poor's 100 (S\&P 100) companies by reviewing Form 10-K information from the Management Discussion and Analysis note, the financial statements, and the leasing footnotes. Our purpose was to quantify the impact of the new leasing standard on the financial statements and related ratios across the variety of firms and industries represented in the S\&P 100.

Similar to the findings of the Bennet and Bradbury 2003 study, we found a material impact on specific firms and on specific industries. Double digit increases and decreases in firm specific financial ratios will occur. In addition, the present study provided insight into the estimates of these changes under a range of discount rates. Since many previous studies employed a $10 \%$ discount rate and since interest rates have generally declined over the intervening period, our study provides more relevant estimates given current market conditions.

Second, our findings support the IASB initiative to capitalize operating leases, ultimately creating a more representative balance sheet. The impact of including operating lease liabilities and assets is apparent throughout our discussion. We agree with the Boards that these leasing arrangements should be represented on the balance sheet if that statement is to reflect the firm's full set of obligations.

Finally, these results should alert those firms and industries that heavily utilize operating leases. Credit ratings, bondholder agreements, and incentive compensation programs are among the host of items that will be affected by lease capitalization. Though our study focused on the interest rate impact of using an incremental borrowing rate to discount the lease payments, the new standard also requires the lease payments to include renewal options and contingent payments in the mix. Standard and Poor's recently acknowledged that these two items "could result in a materially higher amount being capitalized under the proposed ROU model [i.e., the right of use model of the new lease standard] than under our current methodology." " Thus, the new standard will likely result in larger operating lease liabilities than the rating agencies currently incorporate into their present methodology.

\section{AUTHOR INFORMATION}

John Kostolansky received a M.S. and Ph.D in Economics from Columbia University. He is an Associate Professor of Accounting at Loyola University Chicago and has served as Chairman of the Accounting Department and as Associate Dean of the Graduate School of Business. His research interests are in the areas of financial statement analysis, issues in financial reporting, and pension accounting. His publications have appeared in the Journal of Accounting, Auditing, and Finance, Journal of Commercial Bank Lending, Journal of Economic Asymmetries, Journal of Applied Business Research, and the Journal of Business Case Studies. Professor Kostolansky teaches various financial accounting courses in the M.B.A. and M.S. in Accountancy Programs. E-mail: jkostol@luc.edu

Professor Brian Stanko received a B.S. and M.B.A. from Eastern Illinois University and a Ph.D. in Accounting from the University of Kentucky. He is currently Department Chair and MSA Program Director at Loyola University Chicago. Professor Stanko's primary research and writing interests concern financial reporting standards and the understanding of corporate annual reports. He is the coauthor of three books and has published articles in the Journal of Accounting and Public Policy, Issues in Accounting Education, Corporate Controller, The Government Accountants Journal, Strategic Finance, Journal of Business Ethics, The CPA Journal, Journal of Business Case Studies, and International Advances in Economic Research. Professor Stanko's teaching responsibilities have included principles, intermediate, and graduate level accounting courses. E-mail: bstanko@luc.edu

\section{REFERENCES}

1. Annual Reports 10-K, Fortune 100 firms.

2. Beattie, V., Edwards, K., and Goodacre, A. 1998. The impact of constructive operating lease capitalization on key accounting ratios. Accounting and Business Research 28: 233-254.

\footnotetext{
1 "How Proposed Changes To IFRS and U.S. Lease Accounting Requirements Are Likely To Affect Standard \& Poor's Credit Analysis," September 30, 2010 at www.standardandpoors.com/ratingsdirect.
} 
3. Bennet, B. K. and Bradbury, M. E. 2003. Capitalizing non-cancelable operating leases. Journal of International Financial Management and Accounting 14: 101-114

4. Financial Accounting Standards Board. Proposed Accounting Standards Update, Leases (Topic 840), August 17, 2010.

5. Fülbier, R. U., Silva, J. L., and Pferdehirt, M. H. 2008. Impact of lease capitalization on financial ratios of listed German companies. Schmalenbach Business Review 60: 122-144.

6. Imhoff, E. A., Lipe, R. C., and Wright, D. W. 1991. Operating leases: impact of constructive capitalization. Accounting Horizons 5: 51-63.

7. Imhoff, E. A., Lipe, R. C., and Wright, D. W. 1993. The effects of recognition versus disclosure on shareholder risk and executive compensation. Journal of Accounting, Auditing, and Finance Vol. 8, Issue 4:335-368.

8. Ingberman, M., Ronen, J. and Sorter, G. How Lease Capitalization Under FASB Statement No. 13 Will Affect Financial Ratios. Financial Analysts Journal January-February 1979.

9. Mulford, Charles W. 2007. The Effects of Lease Capitalization on Various Financial Measures: An Analysis of the Retail Industry. Georgia Tech Financial Analysis Lab.

10. Securities and Exchange Commission. 2005. Report and Recommendations Pursuant to Section 401(c) of the Sarbanes-Oxley Act of 2002 On Arrangements with Off-Balance Sheet Implications, Special Purpose Entities, and Transparency of Filings by Issuers.

11. Standard and Poor's, "How Proposed Changes To IFRS and U.S. Lease Accounting Requirements Are Likely to Affect Standard \& Poor's Credit Analysis," September 30, 2010 at www.standardandpoors.com/ratingsdirect 
NOTES 